\title{
Biochemical and Anatomical Characters of Snap Bean (Phaseolus vulgaris L.) Pods under Furrow and Drip Irrigation System at Harvest and during Postharvest
}

\author{
El-tahan I. M.; M. A. El-hamahmy*; A. E. Elewa and A. I. Baz \\ Department of Agricultural Botany, Faculty of Agriculture, Suez Canal University, 41522 Ismailia, Egypt
}

Received: 20/4/2016

\begin{abstract}
The biochemical and anatomical analysis of furrow and drip-irrigated pods at harvest and after postharvest were investigated. Results showed that, furrow-irrigated pods were significantly higher in the concentration of vitamin $\mathrm{C}$, free phenolics, protein and proline as well as superoxide dismutase activity than drip-irrigated ones. On the other hand, concentration of free amino acids and activity of catalase were higher in drip-irrigated pods by about 4 and 1.7 times than furrow-irrigated ones, respectively. Both types of pods were similar in chlorophylls, carotenoids, TA (\%), TSS and reducing sugars concentrations. The two pod types were similar in the anatomical parameters studied except that furrow-irrigated pods which showed an increase in the thickness of parenchymatous cells in the pericarp. During storage, furrow-irrigated pods stored at $7 \pm 1^{\circ} \mathrm{C}$ and $85 \% \mathrm{RH}$ for $25 \mathrm{~d}$ showed lower $\%$ of decay, rot, soggy and shriveling, but showed more water loss than drip-irrigated ones at all storage periods. Drip-irrigated pods maintained high concentration of chlorophylls and carotenoid than furrow-irrigated pods until $20 \mathrm{~d}$ of storage. Furrow-irrigated pods preserve the vitamin $\mathrm{C}$ at high concentration at all storage periods. TA (\%) and TSS were increased with storage in both fruit types without any significant differences between them. Both pod types had the same trend in the concentration of organic compounds and the activity of antioxidative enzymes. Furrow-irrigated pods maintained their pericarp and symmetric of cells compared to drip-irrigated ones. It could conclude that furrow irrigation was better to produce visual appearance, high nutritional snap beans with high quality. It can be stored without deleterious effect for $25 \mathrm{~d}$ at $7 \pm 1^{\circ} \mathrm{C}$ and $85 \% \mathrm{RH}$ than drip irrigation.
\end{abstract}

Keywords: Visual appearance, antioxidative enzymes, quality, biochemical and anatomical characters.

\section{INTRODUCTION}

In Egypt, snap bean (Phaseolus vulgaris L., Fabaceae) is one of the most valuable vegetable crops cultivated for local consumption, industry and exporting. It originated in Southern Mexico and warm regions of Guatemala (Singh et al., 1991). It is an excellent source of protein, $\omega-3$ fatty acids, niacin, vitamins $\mathrm{K}, \mathrm{C}, \mathrm{A}$, thiamin, riboflavin, folate, manganese, potassium, iron, copper, calcium and phosphorus. It has significant amounts of fibers which help in lowering blood cholesterol and hence reduce the chance of heart attack or stroke (Ouzounidoua et al., 2012). It is classified in the top ten among other common vegetables in relation to antioxidant content and activity (Ou et al., 2002). World production of green beans annually increased, reached to about $21.4 \mathrm{~m}$ ton in 2013, produced from about $1.54 \mathrm{~m}$ hectare, and China was the first producers by about $16 \mathrm{~m}$ ton. However, Egypt in the $6^{\text {th }}$ rank produced about 263080 ton from 25071 hectare (FAO-STAT, 2013).

Like other plant species, irrigation is an important factor for growth and vigor of both snap bean plant and its pods. The trend in recent years has been towards conversion of furrow to drip irrigation which is considered to be a more efficient water delivery system. The effect of irrigation system on postharvest quality of snap beans hasn't been extensively studied (Sezen et al., 2008). Gabelman and Williams (1960) found that fiber development in pod of green beans is determined by genotypes and temperature than by soil moisture content. However, environmental factors such as temperature and irrigation influence the nutritional status such as ascorbic acid, $\beta$-carotene, essential amino acids and other nutrients of vegetable crops (Harris,
1975). Lee et al. (1977) reported that interlocular cavitation in the susceptible varieties of green bean pods was associated with heavy irrigation during pod growth. However, Drake and Silbernagel (1982) found differential effect of irrigation systems on ascorbic acid content and color of the fresh green bean. The high amount of water with short intervals improved the yield and quality of beans under drip irrigation (Sezen et al., 2008). Although little is known about the effect of irrigation systems on postharvest quality, water shortage during growth has generally deleterious effect on pod weight loss during postharvest (Ferguson et al., 1999). The marketable yield of green bean increased with an increase in seasonal water applied approximately up to $410 \mathrm{~mm}$ and thereafter yield tended to decline (Kuscu et al., 2009).

Postharvest life of snap bean is limited by physiological disorders. Due to its tropical nature, it exhibit physiological disorders known as chilling injuries (CI) when they are exposed to low temperature, depending upon ripeness and variety, which is manifested by grayish scald-like discoloration of the skin, peel shriveling, brown spot incidence, watersoaking, skin pitting, uneven ripening, aroma and flavor reduction during ripening and susceptibility to fungal decay, which seriously reduces the fruit marketability (Watada and Morris, 1966). Poor quality in snap beans is often associated with fibrousness, shriveling due to water loss and chilling injuries and decay due to exposure to inappropriate temperatures (Cantwell, 2004).

It is widely accepted that symptoms of $\mathrm{CI}$ are a consequence of oxidative stress in the tissues occurring when reactive oxygen species (ROS) such as hydrogen 
peroxides, superoxides and hydroxyl radicals are in excess of the scavenging capacity of fresh tissue (Hodges et al., 2004). ROS destroyed the biomolecules in plant cells as DNA, RNA, proteins, Chlorophylls and Carbohydrates. Oxidative damage can be minimized by antioxidant defenses that scavenge or prevent the generation of ROS. Involvement of antioxidant enzymes in regulation of ROS can be followed by measuring superoxide dismutase (SOD), peroxidase (POD) and catalase (CAT) activity during postharvest storage. The first quencher of ROS is SOD, which converts superoxide $\left(\mathrm{O}_{2}{ }^{*}\right)$ to $\mathrm{H}_{2} \mathrm{O}_{2}$ and then CAT destroyed it to $\mathrm{H}_{2} \mathrm{O}+\mathrm{O}_{2}$ as well as POD but through intermediate as ascorbic acid or phenolic compounds (Sherwin, 1990 and El-Malak, 2007). Therefore, the present investigation aimed to compare the biochemical and anatomical characters of furrow and drip-irrigated snap bean pods at harvest and during postharvest period. In addition, the beneficial role of enzymatic and nonenzymatic antioxidant during cold stress was studied.

\section{MATERIALS AND METHODS}

Plant material, agricultural practices and irrigation requirements:

Field experiment was conducted in Helwan Export and Import private orchard, Ismailia Governorate, Egypt $\left(30^{\circ} 58^{\prime} \mathrm{N}\right.$ latitude, $32^{\circ} 23^{\prime} \mathrm{E}$ longitude and $13 \mathrm{~m}$ above sea level) during 2013/14 season. In $15^{\text {th }}$ of December seeds of snap bean, Phaseolus vulgaris, L. cv. Paulista were sown under furrow and drip irrigation system. The experimental plot area was $6 \mathrm{~m}^{2}(2 \mathrm{~m} \times 3 \mathrm{~m})$. Each plot included 5 rows, $20 \mathrm{~cm}$ apart with $3 \mathrm{~m}$ length and $0.4 \mathrm{~m}$ width. Four plots for each irrigation system were distributed according to blocks experimental design.

The climate in this region is almost arid with scarce annual rainfall of about $20 \mathrm{~mm}$ concentrated over the months of December to February, the temperature average is about $15.2^{\circ} \mathrm{C}$ during winter, and the relative humidity average is about $58.3 \%$. The predicted monthly climatic data at Ismailia region during the growing seasons of snap beans are presented in Table (1). Soil physical and chemical properties were analyzed according to Grossmann and Reinsch (2002) and presented in Table (2). Both field capacity and wilting point were determined following the method of Cassel and Nielsen (1986). The irrigation amount was calculated with Penman-Monteith equation (Allen et al., 1998 ) depending on the predicted monthly climatic data (Table 1) during the growing periods $(67 \mathrm{~d}$ from seed sowing until harvest) according to the crop coefficient (Kc) and the daily reference potential evapotranspiration (ETo). The latter was determined by Allen et al. (1996). The FAO Kc of snap bean plant was 0.6 for initial stage, 1.15 for mid-season stage and 0.8 for last-season stage. Irrigation amount was estimated by $1840 \mathrm{~m}^{3} /$ ha per season in furrow irrigation and plant consumed about $477.6 \mathrm{ml}$ of water/season as well as $1081 \mathrm{~m}^{3} / \mathrm{ha}$ per season with consumption about $895.5 \mathrm{ml}$ of water/season in drip irrigation. All cultural practices for snap bean were applied as recommended.

Table (1): The predicted monthly climatic data at Ismailia Governorate during the growing periods of snap beans in 2013/14 season.

\begin{tabular}{|c|c|c|c|c|c|}
\hline \multirow{2}{*}{ Months } & \multicolumn{3}{|c|}{ Average temperature ${ }^{\circ} \mathrm{C}$} & \multirow{2}{*}{ Average RH (\%) } & \multirow{2}{*}{$\begin{array}{c}\text { Average } \\
\text { Wind speed } \\
\text { (m/sec.) }\end{array}$} \\
\hline & Maximum & Minimum & Average & & \\
\hline December & 19.7 & 8.50 & 14.1 & 58.2 & 3.0 \\
\hline January & 21.1 & 9.00 & 15.1 & 58.3 & 3.6 \\
\hline Feb. & 22.7 & 10.3 & 16.5 & 58.4 & 3.5 \\
\hline
\end{tabular}

Data collected from Agriculture Research Center Meteorological Station in Ismailia.

Table (2): Soil physical and chemical properties of the experimental field soil.

\begin{tabular}{|c|c|c|c|c|c|c|}
\hline $\begin{array}{l}\text { Soil depth } \\
\text { (cm) }\end{array}$ & $\begin{array}{c}\text { Sand } \\
(\%)\end{array}$ & $\begin{array}{l}\text { Silt } \\
(\%)\end{array}$ & $\begin{array}{l}\text { Clay } \\
(\%)\end{array}$ & $\begin{array}{c}\text { Hydraulic } \\
\text { conductivity } \\
\left(\mathrm{cm} \mathrm{h}^{-1}\right)\end{array}$ & $\begin{array}{l}\text { Texture } \\
\text { class }\end{array}$ & $\begin{array}{l}\text { Bulk density } \\
\qquad\left(\mathrm{g} \mathrm{cm}^{-3}\right)\end{array}$ \\
\hline $0-60 \mathrm{~cm}$ & 88.91 & 6.18 & 5.31 & 7.50 & Sand & 1.65 \\
\hline $\begin{array}{l}\text { Soil depth } \\
\text { (cm) }\end{array}$ & $\begin{array}{c}\text { Field } \\
\text { capacity }(\%)\end{array}$ & $\begin{array}{c}\text { Wilting point } \\
(\%)\end{array}$ & pH & $\begin{array}{c}\text { Organic matter } \\
(\%)\end{array}$ & & $\begin{array}{c}E C \\
\left(\mathrm{dS} \mathbf{m}^{-1}\right)\end{array}$ \\
\hline $0-60 \mathrm{~cm}$ & 7.6 & 1.50 & 7.62 & 0.29 & & 2.05 \\
\hline
\end{tabular}




\section{Postharvest conditions:}

Precooling pods at $4^{\circ} \mathrm{C}$ for $4 \mathrm{~h}$ were transported to laboratory of Dept. of Agric. Bot. Fac. of Agric., Suez Canal Univ., Ismailia, Egypt. Samples of pods of uniform size and appearance were washed by chlorine solution (100 ppm for 15 min using Clorox 12\%), air dried and held for 1 hour at $18^{\circ} \mathrm{C}$. Each treatment $(100 \mathrm{~g}$ $\approx 25$ pods each) was packed in foam plates $(22 \mathrm{~cm}$ length and $14 \mathrm{~cm}$ width) and covered with perforated polyethylene pages (40 pores with $5 \mathrm{~mm}$ width), as 10 replicates ( 5 plates were used in order to determine weight loss and visual properties; the others were used for chemical properties assessments). Pods were stored at $7 \pm 1{ }^{\circ} \mathrm{C}$ and $85 \%$ relative humidity (RH). Measurements were done at 5 days (d) intervals on 10 pods as 5 replicates of each treatment.

\section{Visual appearances:}

Description of chilling injury (\%) as soggy tissue, brown spots and pericarp shrinking was rated on 125 pods for each treatment at $5 \mathrm{~d}$ intervals. The (\%) of fruit decay symptoms (chilling injuries and rots) were determined for each treatment during storage periods until the end of storage period.

\section{Quantitative analysis:}

Weight loss of pods was calculated as a transpire content of water $(\mathrm{g})$ each 5 days intervals. Total soluble solide (TSS, brix ${ }^{\circ}$ ) was measured by LCII-Digital Refractometer (Medline Scientific, United Kingdom, SR-95 digital, 0-90\%).Total Acidity (TA, \%) was determined by titrating pod sap with $0.05 \mathrm{~N}$ of $\mathrm{NaOH}$ up to $\mathrm{pH} 8.1$, the results were expressed as (\%) of malic acid according to A. O. A. C. (1990). Vitamin C concentration $\left(\mathrm{mg} \mathrm{g}^{-1} \mathrm{FW}\right)$ in the pods was determined by the 2,6 dichlorophenolindophenol method according to Pearson (1970).

\section{Determination of organic compounds:}

All analysis were done using UV/VIS spectrophotometer, PG instrument Ltd, USA. The photosynthetic pigments (chlorophyll a, b and carotenoids) were spectrophotometrically determined at 662, 644 and $440.5 \mathrm{~nm}$, respectively (Arnon, 1949). Total chlorophylls were calculated as sum of Chl. a and Chl. b. To determine the following organic substances, ethanolic extraction of pods was prepared as described by Abdel-Rahman et al. (1975). Free phenolics concentration was determined by a modified FolinCiocalteu method at $650 \mathrm{~nm}$ according to William et al. (1965). Reducing sugars was determined by Nelson's method with alkaline copper and arsenomolybdate reagents as described by Moore (1974) at $540 \mathrm{~nm}$. Total free amino acids concentration was estimated using the method of Rosen (1957) with ninhydrin reagent at 570 $\mathrm{nm}$. Soluble proteins concentration was determined using Bradford method (1976) at $595 \mathrm{~nm}$. Free proline was determined using acid ninhydrine reagent at $520 \mathrm{~nm}$ according to Bates et al. (1973).

\section{Antioxidative enzymes assay:}

According to Urbanek et al. (1991), 0.2 g pods was homogenized by using a mortar and pestle with 0.1 $\mathrm{M}$ phosphate buffer $(\mathrm{pH} 6.5)$ at $4^{\circ} \mathrm{C}$ and stirred for 20 min. The suspension obtained was filtered through one layer of muslin cloth and then centrifuged at $18,000 \times \mathrm{g}$ for $15 \mathrm{~min}, 4^{\circ} \mathrm{C}$. The supernatant was used to determine activity of enzymes and enzyme protein as follows:-

Superoxide dismutase (SOD, E.C.: 1.15.1.1) was assayed by measuring the oxidation of nitrobluetetrazolium at $560 \mathrm{~nm}$. Peroxidase (POD, E.C.: 1.11.1.7) by measuring the oxidation of o-dianisidine at $430 \mathrm{~nm}$. The SOD activity was expressed as unit per $100 \mathrm{mg}$ of protein whereas one unit of peroxidase activity was taken as the change of 1.0 unit of optical density/100 $\mathrm{mg}$ protein minute according to Giannopolitis and Ries (1997). Catalase (CAT, E.C.:1.11.1.6) activity was estimated by measured the oxidation of $\mathrm{H}_{2} \mathrm{O}_{2}$ at $240 \mathrm{~nm}$ in $30 \mathrm{~s}$ intervals for $5 \mathrm{~min}$. The unit of CAT activity was defined as the amount of enzyme, which decomposes $1 \mathrm{mmol} \mathrm{H}_{2} \mathrm{O}_{2} / 100 \mathrm{mg}$ protein min. at $25^{\circ} \mathrm{C}$ (Urbanek et al., 1991).

\section{Anatomical studies:}

According to Willey (1971), pod pericarp specimens were killed and fixed in formalin acetic acid (F.A.A), dehydrated in ethyl alcohol series, embedded in Paraffin wax, sectioned to thickness of $15 \mu$, double stained with Safranin and Light green, cleared in Xylene and mounted in Canada balsam. All measurements were calculated by eyepiece micrometer at $10 \mathrm{x}$ (magnification 100x).

\section{Statistical analyses:}

All data were statistically analyzed as randomized complete blocks design (Steel et al., 1997); using the MSTAT-C statistical package (M-STAT, 1990) and means were separated by LSD test, $P \leq 0.05$.

\section{RESULTS}

\section{Effect of irrigation system on Chemical composition} of snap bean pods at harvest:

Data in Table (3) showed that furrow-irrigated pods were significantly higher in the concentration of vitamin $\mathrm{C}$, free phenolics, soluble protein and proline as well as high activity of superoxide dismutase (SOD) than drip-irrigated ones. Double amount of vitamin $\mathrm{C}$ was detected in furrow-irrigated pods over drip irrigated ones. Also, free phenolics, protein and proline concentration increased by about $22.5,33.8$ and $50.2 \%$ in furrow irrigated pods over drip-irrigated pods, respectively. However, concentration of free amino acids and activity of catalase were higher by 4 and 1.7 times in drip-irrigated pods than furrow-irrigated ones, respectively. Also, drip-irrigated pods had higher activity of peroxidase by $34.8 \%$ than furrow-irrigated ones. There weren't any significant differences in the concentration of chlorophyll a, b, carotenoids, total chlorophylls, total acidity (TA, \%) total soluble solids (TSS) and reducing sugars between the both types of pods.

\section{Pod weight loss (g):}

The loss of water was decreased with the extend of storage period in both types of pods. At all storage periods, drip-irrigated pods lost less water (g) than furrow-irrigated ones (Table 3). The maximum amount of water loss was $13.83 \mathrm{~g}$ in furrow-irrigated pods after $5 \mathrm{~d}$ of storage. Furrow-irrigated pods lost water over the 
Table (3): Chemical characters of furrow and drip-irrigated pods of snap bean at harvest and during different periods of storage at $7 \pm 1{ }^{\circ} \mathrm{C}$ and $85 \% \mathrm{RH}$ for 25 days.

\begin{tabular}{|c|c|c|c|c|c|c|c|c|c|c|c|c|}
\hline \multirow{3}{*}{$\begin{array}{l}\text { Chemical compounds concentration and } \\
\text { enzyme activity }\end{array}$} & \multicolumn{6}{|c|}{ furrow-irrigated pods } & \multicolumn{6}{|c|}{ Drip-irrigated pods } \\
\hline & \multirow{2}{*}{$\begin{array}{c}\text { At } \\
\text { harvest }\end{array}$} & \multicolumn{5}{|c|}{ Storage periods (day) } & \multirow{2}{*}{$\begin{array}{c}\text { At } \\
\text { harvest }\end{array}$} & \multicolumn{5}{|c|}{ Storage periods (day) } \\
\hline & & 5 & 10 & 15 & 20 & 25 & & 5 & 10 & 15 & 20 & 25 \\
\hline Weight loss (g) & 0.00 & $13.83 \mathrm{a}$ & $6.66 \mathrm{a}$ & $6.03 \mathrm{a}$ & $4.46 \mathrm{a}$ & $3.73 \mathrm{a}$ & 0.00 & $10.30 \mathrm{~b}$ & $5.06 \mathrm{~b}$ & $4.26 \mathrm{~b}$ & $1.53 \mathrm{~b}$ & $1.40 \mathrm{~b}$ \\
\hline Chlorophyll a (mg $\left.100 \mathrm{~g}^{-1} \mathrm{FW}\right)$ & $5.87 \mathrm{a}$ & $2.06 \mathrm{a}$ & $3.76 \mathrm{a}$ & $3.10 \mathrm{~b}$ & $2.20 \mathrm{~b}$ & $2.13 \mathrm{~b}$ & $5.73 \mathrm{a}$ & $1.23 \mathrm{~b}$ & $2.70 \mathrm{~b}$ & $4.60 \mathrm{a}$ & $5.06 \mathrm{a}$ & $2.66 \mathrm{a}$ \\
\hline Chlorophyll b (mg $100 \mathrm{~g}^{-1} \mathrm{FW}$ ) & $3.83 \mathrm{a}$ & $1.46 \mathrm{a}$ & $2.66 \mathrm{a}$ & $2.73 \mathrm{~b}$ & $1.86 \mathrm{~b}$ & $1.80 \mathrm{a}$ & $3.77 \mathrm{a}$ & $0.86 \mathrm{~b}$ & $2.60 \mathrm{a}$ & $4.16 \mathrm{a}$ & $4.70 \mathrm{a}$ & $2.16 \mathrm{a}$ \\
\hline Total chlorophylls (mg $100 \mathrm{~g}^{-1} \mathrm{FW}$ ) & $9.70 \mathrm{a}$ & $3.56 \mathrm{a}$ & $6.43 \mathrm{a}$ & $5.83 \mathrm{~b}$ & $4.10 \mathrm{~b}$ & $3.93 \mathrm{a}$ & $9.50 \mathrm{a}$ & $2.10 \mathrm{~b}$ & $5.30 \mathrm{~b}$ & $8.80 \mathrm{a}$ & $9.76 \mathrm{a}$ & $4.83 \mathrm{a}$ \\
\hline Carotenoids (mg $\left.100 \mathrm{~g}^{-1} \mathrm{FW}\right)$ & $4.63 \mathrm{a}$ & $1.56 \mathrm{a}$ & $2.70 \mathrm{a}$ & $2.26 \mathrm{~b}$ & $1.90 \mathrm{~b}$ & $1.83 \mathrm{~b}$ & $4.57 \mathrm{a}$ & $1.06 \mathrm{~b}$ & $2.03 \mathrm{~b}$ & $3.26 \mathrm{a}$ & $3.83 \mathrm{a}$ & $2.46 \mathrm{a}$ \\
\hline Total acidity $(\%)$ & $0.03 \mathrm{a}$ & $0.040 \mathrm{a}$ & $0.043 \mathrm{a}$ & $0.060 \mathrm{a}$ & $0.070 \mathrm{a}$ & $0.110 \mathrm{a}$ & $0.03 \mathrm{a}$ & $0.040 \mathrm{a}$ & $0.050 \mathrm{a}$ & $0.070 \mathrm{a}$ & $0.076 \mathrm{a}$ & $0.090 \mathrm{a}$ \\
\hline Total soluble solids $\left(\right.$ brix $\left.^{\circ}\right)$ & $4.60 \mathrm{a}$ & $5.90 \mathrm{a}$ & $6.66 \mathrm{a}$ & $6.80 \mathrm{a}$ & $6.93 \mathrm{a}$ & $7.03 \mathrm{~b}$ & $4.37 \mathrm{a}$ & $4.26 \mathrm{~b}$ & $5.06 \mathrm{~b}$ & $5.83 \mathrm{~b}$ & $6.33 \mathrm{~b}$ & $7.90 \mathrm{a}$ \\
\hline Vitamin $\mathbf{C}\left(\mathrm{mg} \mathrm{g}^{-1} \mathrm{FW}\right)$ & $6.00 \mathrm{a}$ & $10.83 \mathrm{a}$ & $7.50 \mathrm{a}$ & $6.83 \mathrm{a}$ & $4.00 \mathrm{a}$ & $5.83 \mathrm{a}$ & $2.50 \mathrm{~b}$ & $5.50 \mathrm{~b}$ & $8.00 \mathrm{a}$ & $5.83 \mathrm{a}$ & $3.50 \mathrm{a}$ & $3.00 \mathrm{~b}$ \\
\hline Reducing sugars (mg g ${ }^{-1} \mathrm{FW}$ ) & $31.23 \mathrm{a}$ & $16.33 \mathrm{a}$ & $16.90 \mathrm{~b}$ & $17.03 \mathrm{~b}$ & $15.76 \mathrm{a}$ & $15.50 \mathrm{a}$ & $32.30 \mathrm{a}$ & $14.73 \mathrm{a}$ & $20.00 \mathrm{a}$ & $22.86 \mathrm{a}$ & $15.66 \mathrm{a}$ & $15.56 \mathrm{a}$ \\
\hline Free phenolics (mg $\left.100 \mathrm{~g}^{-1} \mathrm{FW}\right)$ & $125.70 \mathrm{a}$ & $91.43 \mathrm{a}$ & $94.30 \mathrm{a}$ & $147.50 \mathrm{a}$ & $148.90 \mathrm{a}$ & $183.20 \mathrm{a}$ & $102.60 \mathrm{~b}$ & $75.73 \mathrm{~b}$ & $79.66 \mathrm{~b}$ & $118.90 \mathrm{~b}$ & $123.00 \mathrm{~b}$ & $154.76 \mathrm{~b}$ \\
\hline Free amino acids $\left(\mathrm{mg} 100 \mathrm{~g}^{-1} \mathrm{FW}\right)$ & $4.13 \mathrm{~b}$ & $12.06 \mathrm{a}$ & $52.13 \mathrm{a}$ & 75.53 a & $31.83 \mathrm{a}$ & $30.80 \mathrm{a}$ & $16.73 \mathrm{a}$ & $5.80 \mathrm{~b}$ & $13.23 \mathrm{~b}$ & $21.13 b$ & $11.06 \mathrm{~b}$ & $11.06 \mathrm{~b}$ \\
\hline Protein $\left(\mathrm{mg} \mathrm{g}^{-1} \mathrm{FW}\right)$ & $17.17 \mathrm{a}$ & $21.40 \mathrm{a}$ & $22.90 \mathrm{a}$ & $46.26 \mathrm{a}$ & $69.96 \mathrm{a}$ & $63.76 \mathrm{~b}$ & $12.83 \mathrm{~b}$ & $12.13 \mathrm{~b}$ & $19.76 b$ & $46.43 \mathrm{a}$ & $72.00 \mathrm{a}$ & $77.10 \mathrm{a}$ \\
\hline Proline (mg $\left.100 \mathrm{~g}^{-1} \mathrm{FW}\right)$ & $13.37 \mathrm{a}$ & $8.13 \mathrm{a}$ & $8.50 \mathrm{~b}$ & $15.46 \mathrm{~b}$ & $19.20 \mathrm{a}$ & $16.10 \mathrm{a}$ & $8.90 \mathrm{~b}$ & $6.23 \mathrm{a}$ & $13.70 \mathrm{a}$ & $21.80 \mathrm{a}$ & $17.53 \mathrm{a}$ & $8.73 \mathrm{~b}$ \\
\hline Superoxide dismutase (unit $100 \mathrm{~g}^{-1}$ protein min) & $1.43 \mathrm{a}$ & $1.46 \mathrm{~b}$ & $0.67 \mathrm{~b}$ & $0.03 \mathrm{a}$ & $0.02 \mathrm{a}$ & $0.02 \mathrm{a}$ & $0.89 \mathrm{~b}$ & $2.36 \mathrm{a}$ & $1.27 \mathrm{a}$ & $0.03 \mathrm{a}$ & $0.02 \mathrm{a}$ & $0.02 \mathrm{a}$ \\
\hline Peroxidase (unit $100 \mathrm{~g}^{-1}$ protein min) & $4.43 \mathrm{~b}$ & $5.13 \mathrm{a}$ & $5.70 \mathrm{a}$ & $2.40 \mathrm{~b}$ & $1.13 \mathrm{~b}$ & $0.30 \mathrm{a}$ & $5.97 \mathrm{a}$ & $2.30 \mathrm{~b}$ & $3.23 \mathrm{~b}$ & $3.43 \mathrm{a}$ & $1.60 \mathrm{a}$ & $0.40 \mathrm{a}$ \\
\hline Catalase (unit $100 \mathrm{~g}^{-1}$ protein min) & $0.07 \mathrm{~b}$ & $0.073 \mathrm{a}$ & $0.103 \mathrm{a}$ & $0.030 \mathrm{a}$ & 0 & $0 \mathrm{~b}$ & $0.12 \mathrm{a}$ & $0.070 \mathrm{a}$ & $0 \mathrm{~b}$ & $0 \mathrm{~b}$ & 0 & $0.030 \mathrm{a}$ \\
\hline
\end{tabular}

Values followed by the same letter within a row are not significantly different at L.S.D, P $\leq 0.05$ level of probability 
drip-irrigated ones by about 34.3, 31.6 and $41.5 \%$ after 5,10 and $15 \mathrm{~d}$ of storage, respectively. The loss of water increased by about 2.9 and 2.6 times at 20 and $25 \mathrm{~d}$ of storage, respectively.

\section{Photosynthetic pigments concentration in pods:}

At all storage periods, the drip-irrigated pods maintained more chlorophyll a, b and carotenoids concentration than furrow-irrigated pods (Table 3). The concentration of chlorophyll $\mathrm{a}$ and $\mathrm{b}$ increased until 15 and $20 \mathrm{~d}$ of storage in furrow and drip-irrigated pods, respectively then decreased. Total chlorophylls and carotenoids increased until 10 and $20 \mathrm{~d}$ of storage in furrow and drip-irrigated pods, respectively, then decreased. The maximum concentration of chlorophyll $\mathrm{a}, \mathrm{b}$, total chlorophylls and carotenoids was 5.06, 4.7,

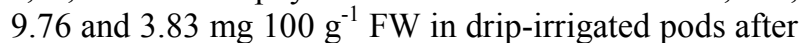
$20 \mathrm{~d}$ of storage, respectively.

\section{Fruit quality:}

TA \% and TSS increased in both types of pods during all storage periods (Table 3 ). The concentration of vitamin $\mathrm{C}$ was increased until 5 and $10 \mathrm{~d}$ of storage in furrow and drip-irrigated pods, respectively. Furrowirrigated fruits showed higher concentration of vitamin $\mathrm{C}$ than drip-irrigated ones. There weren't any significant differences in TA $(\%)$ in both pods types at all storage periods. The maximum value of vitamin $\mathrm{C}(10.83 \mathrm{mg} \mathrm{g}$ $\left.{ }^{1} \mathrm{FW}\right)$ and TA $(0.11 \%)$ were detected after 25 and $5 \mathrm{~d}$ of storage in furrow-irrigated pods and TSS (7.9) in dripirrigated ones at the end of storage, respectively. The values of TSS were only significantly differed at the initial and end period of storage between both types of pods.

\section{Organic compounds concentration:}

Furrow and drip-irrigated pods were similar in the trend of organic compounds concentration during storage (Table 3). Reducing sugars and free amino acids concentrations were increased until $15 \mathrm{~d}$ of storage, and then decreased in both types of pods. Free phenolics and protein were increased at all storage periods in both types of pods. Proline concentration was increased until $20 \mathrm{~d}$ of storage then decreased in both types. Furrowirrigated pods preserve more amounts of amino acids and free phenolic concentrations than drip-irrigated ones, whereas the maximum significant values were 75.53 and $183.2 \mathrm{mg} 100 \mathrm{~g}^{-1} \mathrm{FW}$ after 15 and $25 \mathrm{~d}$ of storage, respectively. However, the drip-irrigated pods gave the maximum significant values of reducing sugars, proline and protein concentration $(22.86,21.8$ and 77.1) after 15 and $25 \mathrm{~d}$ of storage, respectively.

\section{Antioxidative enzymes activity:}

Table (3) showed also that, activity of SOD gradually decreased at all storage periods in both pod types. Peroxidase activity increased until 10 and $15 \mathrm{~d}$ of storage in furrow and drip-irrigated pods, respectively. Catalase activity was increased until $10 \mathrm{~d}$ then decreased in furrow irrigated pods. No activity of CAT was detected after 10 and 20d of storage in furrow and drip-irrigated pods, respectively. The maximum activity of SOD was 2.36 unit $100 \mathrm{~g}^{-1}$ protein min. after $5 \mathrm{~d}$ of storage in drip-irrigated pods. The maximum activity of POD and CAT was 5.7 and 0.103 unit $100 \mathrm{~g}^{-1}$ protein min. after $10 \mathrm{~d}$ of storage in furrow-irrigated pods. SOD activity was higher during $10 \mathrm{~d}$ of storage in dripirrigated pods than furrow-irrigated ones. Peroxidase and catalase activities were higher during $10 \mathrm{~d}$ of storage in furrow-irrigated pods than drip-irrigated ones.

Pods decay, rot (\%) and chilling injuries disorders of furrow and drip-irrigated pods during storage:

Pod decay (\%) was calculated in fruits as sum of fruit rot and chilling injuries disorders during $25 \mathrm{~d}$ of storage at $7 \pm 1^{\circ} \mathrm{C}$ and $85 \% \mathrm{RH}$. Decaying of pods was induced by chilling injuries more than rotting (Table 4). Furrow-irrigated pods showed lower decay (\%) and non-rotted pods than drip-irrigated ones at all investigated periods of storage. However, chilling injuries were observed on fruits as soggy tissues, brown spots and fruit shrinking. Furrow-irrigated pods showed less soggy tissue (\%) than drip-irrigated ones at all investigated periods during storage. There weren't any brown spots on both types of pods until $20 \mathrm{~d}$ of storage but it was detected at the end of storage period. Shrinking of fruits wasn't observed in furrow-irrigated pods until the end of storage and up to $15 \mathrm{~d}$ of storage in drip-irrigated ones.

\section{Anatomical characters of the pericarp at harvest:}

Thickness of epidermis with cuticle, parenchyma between epidermis and fibers, fibrous tissue and vascular bundle at maximum radius of furrow-irrigated pods were higher than drip-irrigated ones (Table 5 and Fig. 1). All previous parameters weren't significantly different except the thickness of parenchyma between epidermis and fibers. Moreover, there weren't any differences in the thickness of pericarp in both furrow and drip-irrigated pods. Lysigenous intercellular spaces in pericarp weren't found and parenchyma cells were symmetric in both types of pods.

\section{Anatomical characters of the pericarp at the end of storage:}

Pericarp in furrow-irrigated pods was doubled in thickness $(\mu \mathrm{m})$ compared to drip-irrigated fruits at the end of storage as shown in (Table 5 and Fig. 1). However, there weren't any differences in thickness of epidermis with cuticle, parenchyma between epidermis and fibers, fibrous tissue and vascular bundle at maximum radius between both types of pods. Lysigenous intercellular spaces and symmetric parenchyma were observed in furrow-irrigated pericarp compared to drip-irrigated pericarp.

\section{DISCUSSION}

Results showed that, pods of snap bean synthesized more secondary metabolites as vitamin $\mathrm{C}$, phenolics and proline. These findings can be explained as plants under furrow irrigation had relatively suffered from water deficit due to the longevity of irrigation periods than drip-irrigated ones. This remark went parallel with that snap bean plant consumed about 477.6 $\mathrm{ml}$ of water/season or $7 \mathrm{ml}$ of water/day in furrow irrigation compared to $895.5 \mathrm{ml}$ of water/season or13.3 $\mathrm{ml}$ of water/day in drip irrigation. Also, the activity of SOD, the first antioxidant enzyme which converts superoxide to hydrogen peroxide was higher. 
Table (4): Total decay, chilling injuries of snap beans at different storage periods at $7 \pm 1{ }^{\circ} \mathrm{C}$ and $85 \% \mathrm{RH}$ for 25 days.

\begin{tabular}{|c|c|c|c|c|c|c|c|c|c|c|c|}
\hline \multirow{3}{*}{\multicolumn{2}{|c|}{$\begin{array}{c}\text { Visual appearances } \\
(\%)\end{array}$}} & \multicolumn{5}{|c|}{ Furrow-irrigated pods } & \multicolumn{5}{|c|}{ Drip-irrigated pods } \\
\hline & & \multicolumn{5}{|c|}{ Storage periods (day) } & \multicolumn{5}{|c|}{ Storage periods (day) } \\
\hline & & 5 & 10 & 15 & 20 & 25 & 5 & 10 & 15 & 20 & 25 \\
\hline \multicolumn{2}{|c|}{ Total decay } & $0 \mathrm{~b}$ & $19.32 \mathrm{~b}$ & $19.32 \mathrm{~b}$ & $19.32 \mathrm{~b}$ & $28.41 \mathrm{~b}$ & $5.88 \mathrm{a}$ & $22.06 \mathrm{a}$ & $26.47 \mathrm{a}$ & $27.94 \mathrm{a}$ & $54.41 \mathrm{a}$ \\
\hline \multicolumn{2}{|c|}{ Pods rot } & 0 & 0 & $0 \mathrm{~b}$ & 0 & $0 \mathrm{~b}$ & 0 & 0 & $11.76 \mathrm{a}$ & 0 & $47.06 \mathrm{a}$ \\
\hline \multirow{3}{*}{ 先 } & Soggy tissues & $0 \mathrm{~b}$ & $77.27 \mathrm{~b}$ & $77.27 \mathrm{~b}$ & $77.27 \mathrm{~b}$ & $86.36 \mathrm{~b}$ & $23.53 \mathrm{a}$ & $88.24 \mathrm{a}$ & $94.12 \mathrm{a}$ & $100 \mathrm{a}$ & $100 \mathrm{a}$ \\
\hline & Brown spots & 0 & 0 & 0 & 0 & $27.27 \mathrm{a}$ & 0 & 0 & 0 & 0 & $23.53 \mathrm{~b}$ \\
\hline & Shrinking & 0 & 0 & 0 & $0 \mathrm{~b}$ & $0 \mathrm{~b}$ & 0 & 0 & 0 & $11.76 \mathrm{a}$ & $47.06 \mathrm{a}$ \\
\hline
\end{tabular}

Values followed by the same letter within a row are not significantly different at L.S.D, P $\leq 0.05$ level of probability

Table (5): Anatomical characters of the pericarp of furrow and drip-irrigated pods at harvest and after 25 days of storage.

\begin{tabular}{|c|c|c|c|c|c|c|c|}
\hline \multirow{2}{*}{$\begin{array}{l}\text { Irrigation } \\
\text { system }\end{array}$} & \multicolumn{5}{|c|}{ Thickness in $\mu \mathrm{m}$ of: } & \multirow{2}{*}{$\begin{array}{c}\text { Lysigenous } \\
\text { intercellular spaces }\end{array}$} & \multirow{2}{*}{ (Un)symmetric Parenchyma } \\
\hline & $\begin{array}{c}\text { Epidermis with } \\
\text { cuticle }\end{array}$ & $\begin{array}{l}\text { Parenchyma between } \\
\text { epidermis and fibers }\end{array}$ & $\begin{array}{l}\text { Fibrous } \\
\text { tissue }\end{array}$ & Pericarp & $\begin{array}{l}\text { Vascular bundle at } \\
\text { maximum radius }\end{array}$ & & \\
\hline \multicolumn{8}{|c|}{ At harvest } \\
\hline Furrow & $5.23 \mathrm{a}$ & $85.23 \mathrm{a}$ & $5.23 \mathrm{a}$ & $253.33 \mathrm{a}$ & $8.90 \mathrm{a}$ & - & Symmetric \\
\hline Drip & $4.77 \mathrm{a}$ & $66.67 \mathrm{~b}$ & $4.30 \mathrm{a}$ & $255.57 \mathrm{a}$ & $5.70 \mathrm{a}$ & - & Symmetric \\
\hline \multicolumn{8}{|c|}{ After $25 \mathrm{~d}$ of storage } \\
\hline Furrow & $3.83 \mathrm{a}$ & $62.86 \mathrm{a}$ & $5.70 \mathrm{a}$ & $248.86 \mathrm{a}$ & $15.56 \mathrm{a}$ & + & Symmetric \\
\hline Drip & $3.83 \mathrm{a}$ & $62.86 \mathrm{a}$ & $5.23 \mathrm{a}$ & $177.76 \mathrm{~b}$ & $13.33 \mathrm{a}$ & - & Unsymmetric \\
\hline
\end{tabular}

Values followed by the same letter within a column are not significantly different at L.S.D, $\mathrm{P} \leq 0.05$ level of probability. 


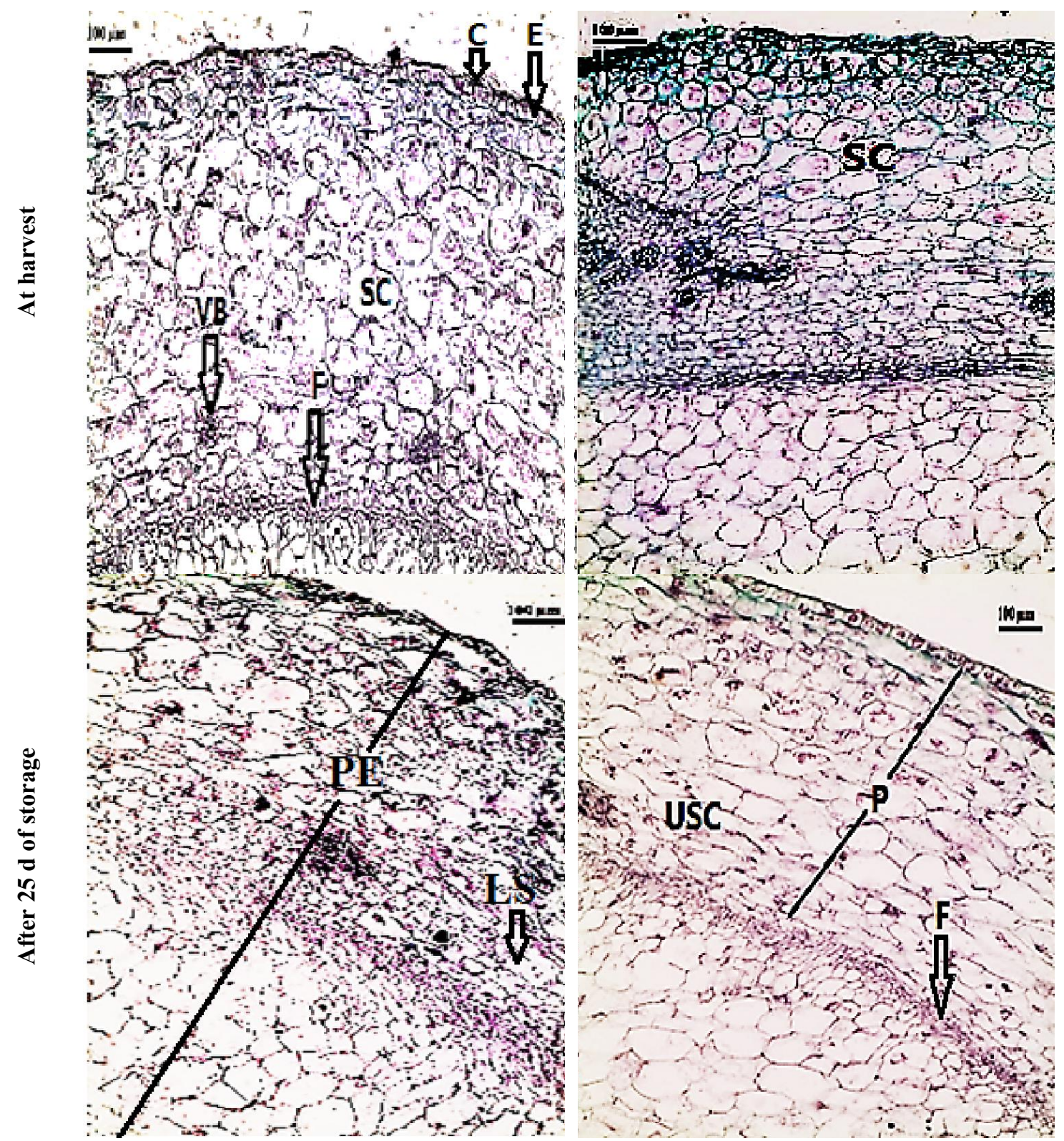

Fig. (1): Transverse sections (100X) of the pericarp of furrow and drip-irrigated pods of snap bean at harvest and after 25d of storage, E (Epidermis); C (Cuticle); P (Parenchyma); PE (Pericarp); F (Fibrous tissue); VB (Vascular bundle);

LS (Lysigenous intercellular spaces); SC (Symmetric Parenchyma); USC (Unsymmetric Parenchyma).

Similar results were reported by Toivonen et al. (1994), Sorensen et al. (1995), and Taiz and Zeiger (2002). In this context, Harris (1975) reported that content of ascorbic acid and other nutrients of vegetable crops depended on irrigation and rainfall rate.

On the other hand, no differences were found in the concentration of all determined photosynthetic pigments as chlorophyll a, b, total chlorophylls, carotenoids, TA (\%), TSS and reducing sugars between furrow and drip-irrigated pods. These results disagreed with Harris (1975), who reported that content of Bcarotene and essential amino acids differed according to irrigation and rainfall rate.

During storage, decaying of pods was induced by chilling injuries more than rotting (Table 2). These results may be due to the efficiency of chlorine sterilization (Soltan et al., 2006). Low decay \% was accompanied by high initial concentration of furrowirrigated pods in antioxidant enzyme, SOD and nonenzymatic compounds, vitamin $\mathrm{C}$, proline and phenolics which quenched different types of reactive oxygen species (ROS), responsible for cell destruction (Shewfelt and Del-Rosario, 2000). Taiz and Zeiger (2002) added that, cuticle layer represented external barrier against pathogens.

Low soggy tissue contributed with the high water loss of furrow-irrigated pods compared to drip-irrigated ones. Therefore, its water content gradually decreased. Brown spots may not be correlated with formation of ROS in pod cells, which contributed with the minimum activity of SOD. Results are in agreement with Cantwell (2004) and Zong et al. (1992) who found that general 
symptoms of CI in snap beans include opaque discoloration of the entire bean, surface pitting, russeting, brown elongated spots, and water loss. Also, at $5-7.5^{\circ} \mathrm{C}$, the most common symptom of $\mathrm{CI}$ is the appearance of isolated rusty brown spots. Low shriveling contributed with the lower loss of water and thereby cell turgidity (Table 4) as well as symmetric of cells, especially in furrow-irrigated pods. High water loss contributed with rapture of pod cell walls (lysigenous cells) as shown in cross section of furrowirrigated pods compared to drip-irrigated ones (Table 5 and Fig. 1).

The lower water loss in drip-irrigated pods contributed with the high concentration of reducing sugars (Table 3 ) which cohesive the water molecules in cell vacuoles (Taiz and Ziger, 2002). Also, Kays (1991) found that, exposure of snap beans to chilling temperatures (at 0 or $5^{\circ} \mathrm{C}$ ) might have resulted in loss of cell membrane integrity and leakage of solutes and water, which often leads to manifest of CI symptoms such as pitting and wilting. In addition, weight loss was significantly decreased in all periods of storage for all treatments under study, due to reduction of transpiration and respiration rate under cooling (Taiz and Ziger, 2002).

The activity of SOD, POD and CAT enzyme decreased in most cases with storage due to the longterm of storage $(25 \mathrm{~d})$. No activity of CAT was determined in the final periods of storage, may be due to snap bean dependence on SOD which firstly quenched superoxide radicals and subsequent POD which transform hydrogen peroxide with ascorbic acid or phenolics as intermediate to water molecules and oxygen under cold stress. These results were coordinated with Ray (2006) who found that plants often develop thick cuticles when grown under water shortage conditions compared to adequate water conditions around the root zone. Burzo et al. (1994) found that, beans stored at 0 or $3^{\circ} \mathrm{C}$ for 10 days developed CI pitting that showed deterioration of the epidermal and first layer of hypodermal cells and was later invaded by fungi, while pit-free tissue maintained its characteristic structure. Watada and Morris (1966) reported that, as the pod became yellow, the endocarp began to collapse and internal cavities formed. The quality declined more rapidly at the beginning of storage than later on, and after approximately 10-12 days at $15^{\circ} \mathrm{C}$ quality of cvs. Top Crop, Romano, Tender green and Blue Lake snap beans was considered fair. These results demonstrated that, furrow-irrigated pods were more tolerant to postharvest quality loss compared to drip-irrigated ones, due to preservations of its pericarp from collapse. Also, the cold storage improved the quality of pods, whereas its fibrous tissue was decreased.

\section{CONCLUSION}

Furrow irrigation system was beneficial tools to produce high nutritional snap beans compared to drip irrigation system. Furrow-irrigated pods can be stored for $25 \mathrm{~d}$ at $7 \pm 1^{\circ} \mathrm{C}$ and $85 \% \mathrm{RH}$ without decay or chilling injuries compared to drip-irrigated pods.

\section{REFERENCES}

A. O. A. C. (1990). Methods of Analysis. Association of Official Analytical Chemists, 14 Ed., Washington, USA.

Abdel-Rahman, T., H. Thomas, G. J. Doss and L. Howell (1975). Changes in endogenous plant hormones in cherry tomato fruits during development and maturation. Physiol. Plant., 34 (1): 39-43.

Allen, R. G., L. S. Pereira, D. Raes and M. Smith (1998). Crop Evapotranspiration Guidelines for Computing Crop Water Requirements (Irrigation and drainage paper 56). FAO of the United Nations, Rome, Italy.

Allen, R. G., M. Smith, O. Willian, W. O. Pruitt and L. S. Pereira (1996). Modifications to the FAO crop coefficient approach. In: Proceedings of the International Conference on Evapotranspiration and Irrigation Scheduling, American Society of Agricultural Engineering, San Antonio, TX, USA, November, 3(6): 132-142.

Arnon, D. I. (1949). Copper enzymes in isolated chloroplasts: phenol oxidase in Beta vulgaris. Plant Physiol., 24: 1-15.

Bates, L. S., R. P. Waldren and I. D. Teare (1973). Rapid determination of free proline for water stress studies. Plant Soil, 39: 205-207.

Bradford, M. A. (1976). Rapid and sensitive method for the quantitation of protein utilizing the principle of protein-dye binding. Annu. Rev. Biochem., 72: 248-254.

Burzo, I., A. Amariueti and C. Craciun (1994). Effect of low temperature on some physiological and ultrastructural changes of sweet pepper, eggplants and pod beans. Acta Horticulturae, 368: 598-607.

Cantwell, M. (2004). "Beans." In The Commercial Storage of Fruits, Vegetables, and Florist and Nursery Crops, edited by K.C. Gross, C.Y.

Cassel, D. K. and D. R. Nielsen (1986). Field capacity and available water capacity. Methods of Soil Analysis. Part I. Physical and Mineralogical Methods. Agronomy Monograph No. 9, In: Klute, A. (ed.) Soil Sci. Soc. Am., Madison, Wisconsin, p 901-926.

Drake, S. R. and M. J. Silbernagel (1982). The influence of irrigation and row spacing on the quality of processed snap beans. J. Am. Soc. Hortic. Sci., 107, 239-242.

El-Malak, G. A. A. (2007). Evaluation of free radical scavenging by natural antioxidants in some fresh, blanched, cold and frozen storage of vegetables. Annals of Agricultural Science (Cairo); 52: 2, 367-374.

FAO-STAT (2013). Agricultural Data. http:// faostat.fao.org/ (last accessed, 1 June 2013).

Ferguson, I. B., R. Volz and A. Woolf (1999). Preharvest factors affecting physiological disorders of fruit. Postharvest Biol. Technol., 15: 255-262. 
Gabelman, W. H. and D. D. F. Williams (1960). Developmental studies with irrigated snap beans. Wis., Agric. Exp. Stn., Bull. 221, pp. 1-56.

Giannopolitis, C. and S. Ries (1997). Superoxid desmutase. I. Occurence in higher plant. Plant Physiol., 59: 309-314.

Grossmann, R. B. and T. G. Reinsch (2002). Bulk density and linear extensibility, in: Methods of Soil Analysis. Part 4. Physical Methods. SSSA Book Series, No. 5, Soil Science Society Am., Madison, Wisconsin, p 201-228.

Harris, R. S. (1975). Effects of agricultural practices on the composition of foods. 1. Effects of agricultural practices on foods of plant origin. In Nutritional Evaluation of Food Processing. $2^{\text {nd }}$ Edition, pp. 33-57. R. S. Harris and E. Karmas (Editors). AVI Publishing Co., Westport, CT.

Hodges, D. M., G. E. Lester; K. D. Munro and P. M. A. Toivonen (2004). Oxidative stress: importance for postharvest quality. Hortscience, 39: 924929.

Kays, S. J. (1991). Stress in harvest products. In Postharvest Physiology of Perishable Plant Products, edited by J. K. Stanley, pp. 335-407. Van Nostrand Reinhold, New York.

Kuscu, H., B. Cetin and A. Turhan (2009). Yield and economic return of drip-irrigated vegetable production in Turkey. New Zealand Journal of Crop and Horticultural Science, 37(1): 51-59

Lee, J. M., P. E. Read and D. W. Davis (1977). Effect of irrigation on interlocular cavitation and yield in snap beans. J. Amer. Soc. Hortic. Sci., 102: 276278.

Moore, T. C. (1974). Research experiences in plant physiology. A laboratory manual. Springerverlage. Berlin, Heidelberg, p: 3-12.

M-STAT. (1990). A Microcomputer Program for the Design, Management and Analysis of Agronomic Research Experiments. Michigan State University.

Ou, B., D. Huang, M. Hampsch-Woodill, J. A. Flanagan and E. K. Seemer (2002). Analysis of antioxidant activities of common vegetables employing oxygen radical absorbance capacity (ORAC) and ferric reducing antioxidant power (FRAP) assays: A comparative study. Journal of Agricultural and Food Chemistry, 50: 31223128.

Ouzounidouaa, G.., M. Asfiaa and F. Gaitisbb (2012). Postharvest application of various chemical factors and their effects on quality characteristics and microbial load of raw beans (Phaseolus vulgaris L.). Acta Alimentaria, 41(3): 363-374.

Pearson, D. (1970). The chemical analysis of foods $\left(6^{\text {th }}\right.$ ed.), T. A Constable, London.

Ray, F. E. (2006). Esau's Plant anatomy: meristems, cells, and tissues of the plant body: their structure, function, and development. $3^{\text {rd }}$ ed. John Wiley and Sons, pp. 607.

Rosen, H. (1957). A modified ninhydrin colourimetric analysis for amino acids. Arch. Biochem. Biophys, 67: 10-15.

Sezen, S. M., A. Yazar; A. Akyildiz, H. Y. Dasgan and B. Gencel (2008). Yield and quality response of drip irrigated green beans under full and deficit irrigation. Scientia Horticulturae, 117: 95-102.

Sherwin, E. R. (1990). Antioxidants. In: Food Additives, (Eds. A. L. Branen, P. M. Davidson and S. Salminen). Marcel Dekker, New York, pp. 139-193.

Shewfelt, R. L. and B. A. Del-Rosario (2000). The role of lipid peroxidation in storage disorders of fresh fruits and vegetables. Hortscience, 35(4): 525530.

Singh, S. P., P. Gepts and D. G. Debouck (1991). Races of common bean (Phaseolus vulgaris L., Fabaceae). Econ. Bot., 45: 379-396.

Soltan, H. H. M., T. J. Abd-Elrahman and A. M. A. Naffa (2006). The efficacy of preharvest salts treatments on incidence of snap bean pod rots during storage. Egypt. J. Phytopathol., 34(1): 3140.

Sorensen, J. N., A. S. Johansen and K. Kaack (1995). Marketable and nutritional quality of leeks as affected by water and nitrogen supply and plant age at harvest. J. Sci. Food Agric., 68: 367-373.

Steel, R. G. D., J. H. Torrie and D. A. Diskey (1997). Principles and Procedures of Statistics: A Biometrical Approach. $3^{\text {rd }}$ ed. Mc Graw-Hill, New York.

Taiz, L. and E. Zeiger (2002). Plant physiology. Sinauer Associates, $3^{\text {rd }}$ ed. p. 690.

Toivonen, P. M. A., B. J. Zebarth and P. A. Bowen (1994). Effect of nitrogen fertilization on head size, vitamin $\mathrm{C}$ content and storage life of broccoli (Brassica oleracea var. italica). Can. J. Plant Sci., 74: 607-610.

Urbanek, H., E. Kuzniak-Gebarowska and K. Herka (1991). Elicitation of defense response in bean leaves by Botrytis cinerea polygala cturonase. Acta Physiol. Plant., 13: 43-50.

Watada, A. E. and L. L. Morris (1966). Effect of chilling and non-chilling temperatures on snap bean fruits. Proc. Amer. Soc. Hort. Sci., 89: 368374.

Willey, R. L. (1971). Microtechnique, A laboratory guide. Mc. Millan publishing Inc., N. Y, p. 99.

William, H. P., A. C. Chichilo and H. Reynolds (1965). Official methods of analysis of the association of agricultural chemists. $10^{\text {th }} \mathrm{ed}$, Ass. of Agric. Chem., Washington, D. C, p. 158.

Zong, R. J., M. Cantwell, L. Morris and V. Rubatzky (1992). Postharvest studies on four fruit-type Chinese vegetables. Acta Horticulturae, 318: 345-354. 


\section{الصفات الكيميائية والتشريحية لقرون الفاصوليا الخضراء تحت نظامي الري بالغمر والتثقيط أثناء الحصاد وما بعد الحصاد الفياد}

إيهاب محمود صالح الطحان ، محمد على محمود الحماحمى" ، عبد الرحمن عليوة حسن ، عبد الغنى إبراهيم باز

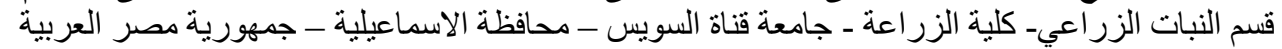

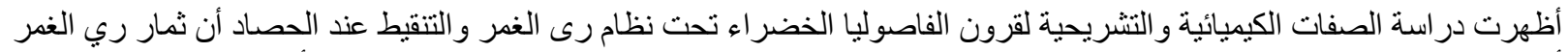

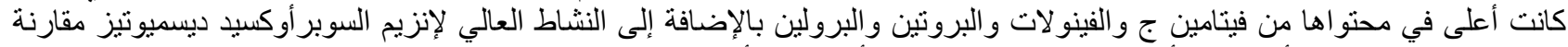

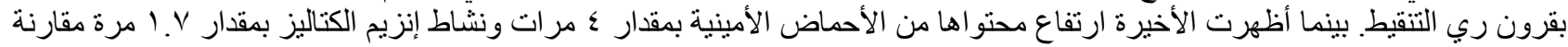

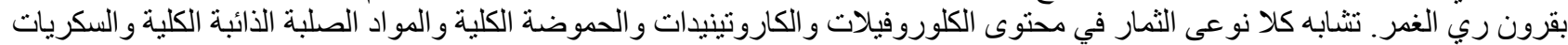

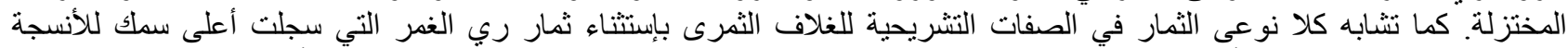

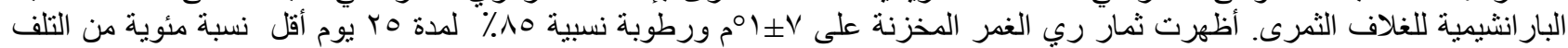

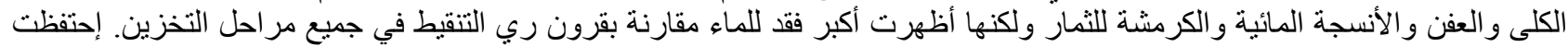

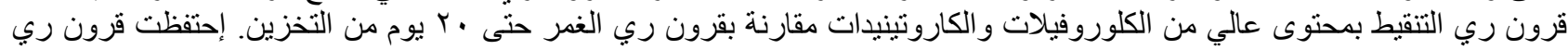

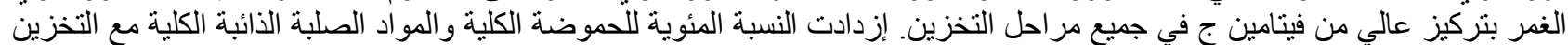

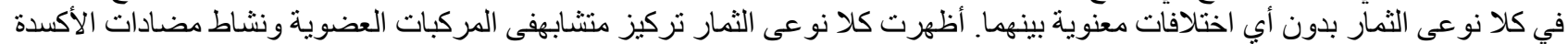

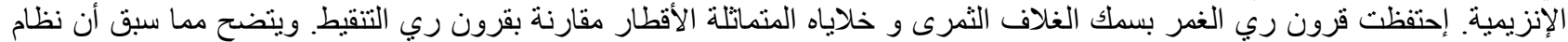

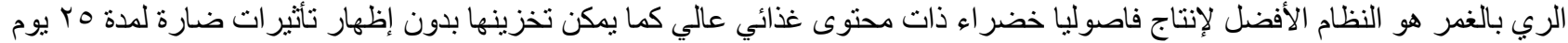

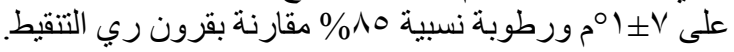

